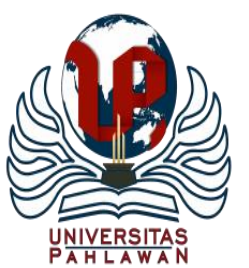

Jurnal Abdidas Volume 1 Nomor 3 Tahun 2020 Halaman 100 - 108 JURNAL ABDIDAS

Community Development Service on Educational and Health Sciences http://abdidas.org/index.php/abdidas

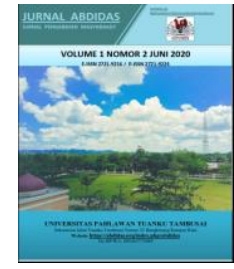

\title{
PELATIHAN SOFT SKILL PENULISAN KREATIF PADA GENERASI MILENIAL DI KOTA LANGSA
}

\author{
Hanif Harahap ${ }^{1}$, Dini Ramadhani ${ }^{2}$ \\ Universitas Samudra, Langsa, Indonesia ${ }^{1,2}$ \\ E-mail: hanifharahap@unsam.ac.id ${ }^{1}$, diniramadhani@unsam.ac.id ${ }^{2}$
}

\begin{abstract}
Abstrak
Menulis merupakan salah satu bagian dari literasi. Menurut penelitian IKAPI 2014 jumlah buku yang terbit dan terdaftar ISBN yaitu 44.327 judul buku. Jumlah ini lebih rendah dibandingkan dengan Tiongkok yang mencapai 440.000 judul buku. Untuk wilayah Provinsi Aceh wilayah pengabdian kepada masyarakat hanya ada 3 penerbit buku yang menjadi anggota IKAPI. Artinya masih sangat minim untuk akses penerbitan buku yang di Provinsi Aceh, bahkan untuk Kota Langsa. Salah satu cara meningkatkan semangat literasi adalah melalui pelatihan bagi generasi milenial Kota Langsa agar dapat meningkatkan soft skill menulis kreatif. Metode dalam pelatihan ini adalah dengan mempratekkan cara menulis kreatif dengan teknik quantum writer. Hasil pelatihan ini para peserta pelatihan meningkat semangat literasi dan soft skill dalam menulis kreatif pada generasi milenial di Kota Langsa. Peserta mendapatkan pengetahuan tentang tahap menulis kreatif dengan teknik quantum writer. Peserta mengetahui tahapan cara pengiriman dan penerbitan naskah karya tulis. Serta peserta menghasilkan draf tulisan dari ide para peserta yang dapat dikembangkan lagi sampai diterbitkan nantinya.
\end{abstract}

Kata kunci: soft skill, penulisan kreatif, generasi milenial

\begin{abstract}
Writing is one part of literacy. According to the IKAPI research on 2014, the number of books published and registered by ISBN is 44,327 titles. This number is lower compared to China which reached 440.000 book titles. For the Province of Aceh, there are only 3 book publishers who are members of IKAPI. This means that there is still very little access to book publishing in the Province of Aceh, even for the city of Langsa. One way to increase the spirit of literacy is through training for millennial generation Langsa City can improve their creative writing skills. The method in this training is to practice how to write creatively using quantum writer techniques. The results of the training increased the enthusiasm of literacy and soft skills in creative writing in the millennial generation in Langsa City. Participants become aware of how to creative writing with quantum writer techniques. Participants knows how to send and publish manuscripts. Gain knowledge about the stages of sending and publishing manuscripts. As well as the participants produce written drafts of the ideas of the participants which can be further developed until published later.
\end{abstract}

Keywords: soft skill, creative writing, millennial generation

Copyright (c) 2020 Hanif Harahap, Dini Ramadhani

\footnotetext{
$\triangle$ Corresponding author :

Address : Langsa

Email : diniramadhani@unsam.ac.id

Phone : 085274779988

DOI: https://doi.org/10.31004/abdidas.v1i3.32
}

ISSN 2721-9224 (Media Cetak) 
DOI: https://doi.org/10.31004/abdidas.v1i3.32

\section{PENDAHULUAN}

Ingin mencurahkan pendapat dapat dilakukan dengan menulis. Disetiap bagian hidup manusia pasti terdapat kegiatan menulis. Dengan menulis, kita dapat merangkai kata menjadi kalimat yang bermakna untuk disampaikan kepada orang lain. Menulis merupakan kemampuan berinteraksi dengan orang lain baik secara langsung maupun tidak langsung (Tarigan, 2008, p. 3). Dalam menulis melibatkan berbagai kemampuannya seperti memilih ide, menyusun kalimat dalam bentuk kata-kata, kebermaknaan, dan kesesuaian dengan tata bahasa. Sehingga dalam menulis membutuhkan keterampilan yang cukup komplek.

Menulis dapat menyampaikan segala hal seperti peristiwa, pendapat, fakta agar para pembaca mendapat pengetahuan baru dari si penulis. Dengan menulis dapat mendidik pembaca dengan menambah wawasan. $\mathrm{Si}$ penulis mengemukakan ide mereka yang dapat diterima atau bahkan ditolak oleh si pembaca. Segi lain tujuan menulis adalah untuk menghibur para pembaca bisa dalam bentuk novel, puisi, pantun, dan lain sebagainya.

Menulis merupakan sarana untuk mengekspresikan diri, penulis dapat mengungkapkan perasaan yang tidak bisa diutarakan secara lisan. Melalui tulisan kita dapat meyakinkan orang lain dengan pengetahuan dan ide yang kita miliki agar mereka juga ikut meyakini juga. Sehingga dengan tersalurkan ide melalui menulis akan mendapat kepuasaan tersendiri dan meningkatkan harga diri. Sehingga nantinya akan tercipta karya tulis lainnya. Jika karya tulis mendapatkan hati masyarakat maka secara non material penulis akan memperoleh popularitas. Secara material, menulis dapat memperoleh penghasilan jika karya tulis diterbitkan dan dikomersialkan.

Menulis dapat membuat seseorang dapat mengungkapkan ide atau pesan agar orang lain juga dapat mengetahui ide yang ia miliki. Sehingga tulisan seseorang harus dipublikasi secara masal. Publikasi tulisan dapat dilakukan pada media massa, buku, media elektronik, dan lain sebagainya. Dengan publikasi seorang penulis akan mengetahui kebermaknaan tulisan mereka untuk memberikan informasi kepada masyarakat.

Menulis erat kaitannya dengan literasi. Beradasarkan hasil PISA tahun 2018 tingkat literasi berada pada posisi nomor 6 paling bawah dari 79 negara peserta (OECD, 2019). Hal ini disebabkan oleh kemampuan menulis seseorang. Permasalahannya adalah seseorang tidak tahu tujuan mereka untuk menulis sehingga tidak mempunyai minat terhadap kegiatan ini. Kurangnya perbendaharaan kata yang dimiliki menjadi permasalahan dalam menulis. Kurangnya imajinasi serta kreativitas untuk menulis.

Data dari PISA juga berbanding lurus dengan hasil penelitian IKAPI. Menurut penelitian IKAPI (IKAPI, 2015) hasil risetnya pada tahun 2014 jumlah buku yang terbit dan terdaftar ISBN yaitu 44.327 judul buku. IKAPI juga mengatakan rata-rata penerbitan buku setiap tahunnya ada 30.000 judul di Indonesia. Jumlah ini lebih rendah dibandingkan dengan Tiongkok yang mencapai 440.000 judul buku dan Amerika Serikat sebanyak 304.912 judul buku. Serta Jepang dengan 42.589 judul buku. Hal ini merupakan masasalah karena Indonesia jauh tertinggal dan jumlah buku yang 
terbit. Artinya hanya sebagian kecil buku yang dapat diterbitkan jika di dibandingkan dengan 264 juta jiwa penduduk Indonesia. Untuk wilayah Provinsi Aceh wilayah pengabdian kepada masyarakat hanya ada 3 penerbit buku yang menjadi anggota IKAPI. Artinya masih sangat minim untuk akses penerbitan buku di Provinsi Aceh, bahkan untuk Kota Langsa.

Mitra pengabdian masyarakat yang bertempat di Kota Langsa. Lokasi keberadaan mitra pengabdian berada suatu wilayah perbatas antara Provinsi Aceh dengan Provinsi Sumatera Utara. Karena jarak Kota Langsa dengan ibu kota Provinsi Aceh yang cukup jauh maka akses penerbitan buku menjadi terkendala. Hal ini membuat penulis terkendala untuk mempublikasikan karya tulis mereka. Selain itu kurangnya pengetahuan masyarakat dalam cara pengiriman dan penerbitan buku di Kota langsa. Belum ada komunitas atau penggerak literasi menulis yang berada di wilayah ini. Sehingga akses para penulis menjadi terbatas dan belum mempunyai pengetahuan untuk hal tersebut.

Jumlah penduduk Kota Langsa sekitar 174.318 jiwa. Hampir sepertiga dari penduduk Kota Langsa banyak yang berasal dari generasi milenial. Usia generasi milenial dari umur 19-37 tahun berjumlah sekitar 60.250 jiwa pada tahun 2017 (BPS, 2018, p. 4). Jumlah generasi milenial ini sangat potensial untuk menghasil karya tulis dari Kota Langsa. Sedangkan jumlah karya yang terbatas ini menjadi persoalan bagi daerah ini. Masyarakat belum mempunyai pengetahuan tentang mendapat ide kreatif dalam menulis. Jika mempunyai ide pun belum mengetahui cara mengeksekusi ide-ide yang dimiliki. Masyarakat belum mengetahui tahap-tahap menulis kreatif. Disamping itu belum ada wadah atau tempat berbagi informasi tentang menulis kreatif untuk dapat memotivasi para penulis untuk menghasilkan karya.

\section{METODE}

Kegiatan pengabdian masyarakat ini dilaksanakan dengan dua metode yaitu presentasi dan praktik.

\section{Metode Presentasi}

Metode presentasi dipilih untuk memberikan pengetahuan kepada masyarakat tentang sosialisasi contoh buku yang telah terbit yaitu buku Laskar Revolusioner Sumatera Timur yang ditulis oleh Tim Pengabdian. Selanjutnya memberikan pengetahuan tentang langkah menulis kreatif. Serta menjelaskan tata cara pengiriman dan penerbitan naskah karya tulis.

\section{Metode Praktik}

Metode ini gunakan agar peserta dapat berlatih menulis melalui bimbingan pelatih. Serta mencobakan teknik menulis dengan quantum writer yang belum pernah mereka ketahui selama ini. Dengan kegiatan praktik, pelatih dapat melihat kemampuan peserta setelah diberikan pelatihan cara menulis kreatif serta cara mempublikasikannya. 
DOI: https://doi.org/10.31004/abdidas.v1i3.32

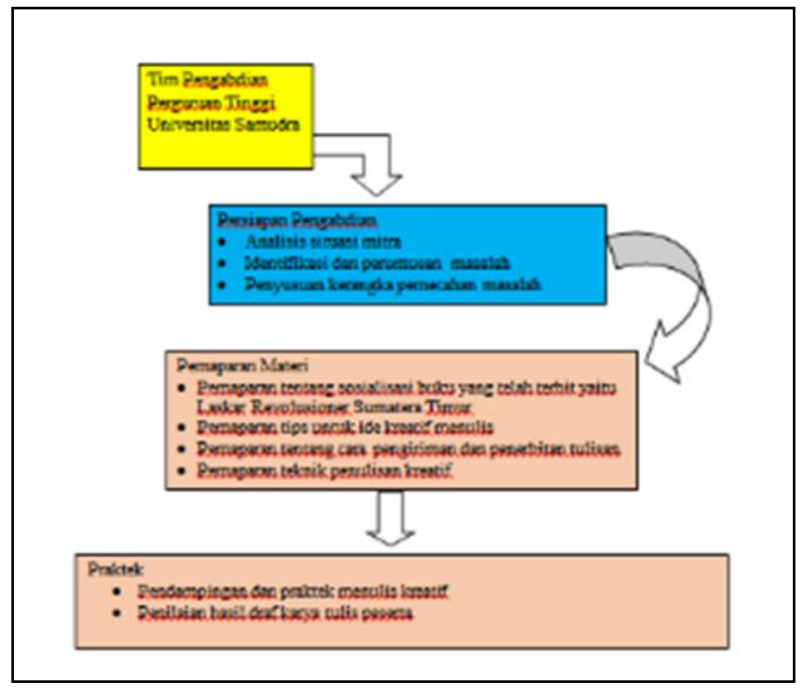

Gambar 1. Kegiatan yang Akan Ditransfer Kepada Peserta

Adapun langkah yang dilakukan pada kegiatan ini yaitu:

\section{Tahap Awal}

Pada tahap ini dilakukan persiapan agar kegiatan dapat berjalan lancar. Beberapa hal yang dilakukan yaitu secara internal tim membagi tugas, merencakan cara pelaksanaan, melengkapi peralatan yang akan digunakan, dan sebagainya.

\section{Tahap Pelaksanaan}

Pada tahap ini dilakukan pelatihan yang diberikan kepada masyarakat generasi milenial Kota Langsa. Ada dua langkah pada tahap ini yakni.

\section{a. Presentasi}

Mempresentasikan pengetahuan tentang sosialisasi contoh buku yang telah terbit yaitu buku Laskar Revolusioner Sumatera Timur yang ditulis oleh tim pengabdian. Selanjutnya memberikan pengetahuan tentang langkah menulis kreatif. Serta menjelaskan tata cara pengiriman dan penerbitan naskah karya tulis. Materi yang disajikan disesuaikan dengan bidang kemampuan yang masing-masing anggota tim.

\section{b. Penugasan Praktik}

Setelah mendapat pengetahuan tentang menulis kreatif dengan teknik quantum writer peserta diminta untuk mempratekkannya. Dibawah bimbingan pelatih dalam 5 kali pertemuan peserta secara bertahap menyerahkan hasil tulisan mereka. Kemudian pelatih akan memberikan beberapa revisi untuk dikembalikan kepada para peserta. Pelatih mengarahkan agar tulisan yang dihasilkan dapat berkualitas. Serta peserta dapat berdiskusi tentang hambatan selama pratek menulis.

\section{Tahap Penilaian}

Pada tahap ini hasil pekerjaan peserta akan dievaluasi oleh pelatih. Pelatih akan membaca dan menganalisis hasil karya peserta untuk menentukan tulisan yang layak untuk dikembangkan menjadi buku .

\section{Tahap Akhir}

Pada kegiatan ini peserta dan tim akan melihat dari awal sampai akhir kegiatan apakah terdapat kelebihan atau kekurangan dari kegiatan ini. Tim mengumpulkan saran dan masukan dari peserta terhadap kegiatan yang dilakukan. Tindakan ini dilakukan mengingat bahwa tim berencana menyebarkan panduan menulis kreatif yang telah dirancang agar dapat dimanfaatkan oleh masyarakat luas yang membutuhkan.

\section{HASIL DAN PEMBAHASAN}


Kegiatan Pengabdian kepada Masyarakat Mandiri ini dilaksanakan dalam lima tahapan yang terdiri atas: (1) pemaparan tentang sosialisasi buku yang telah terbit, (2) pemaparan tips untuk ide kratif menulis, (3) pemaparan tentang cara pengiriman dan penerbitan tulisan, (4) pemaparan teknik penulisan kreatif, dan (5) pendampingan dan praktik tentang menulis kreatif. Berikut pemaparan setiap tahap kegiatan Pengabdian kepada Masyarakat Mandiri.

\section{Pemaparan tentang sosialisasi buku yang} telah terbit

Kegiatan pemaparan ini dilakukan di Gedung Multi Guna Universitas Samudra. Jumlah peserta yang hadir dalam kegiatan tahapan pertama ini sebanyak 80 orang. Pada kegiatan ini dijelaskan contoh buku yang telah terbit yang ditulis oleh tim Pengabdian kepada Masyarakat, Hanif Harahap, M.Pd dan Dini Ramadhani, M.Pd. Buku ini berjudul Laskar Revolusioner Sumatera Timur yang diterbitkan pada bulan Februari Tahun 2019. Buku ini merupakan buku referensi dalam bidang ilmu sosial dan politik. Buku ini telah terdaftar dengan nomor ISBN 978-623-209-0460-0.

Buku ini dipaparkan untuk memberikan contoh kepada peserta untuk menulis buku. Buku Laskar Revolusioner Sumatera Timur ini ditulis dengan mendapat data-data akurat agar menghasilkan tulisan yang bagus. Beberapa dokumen digunakan sebagai sumber primer dalam buku ini, diantaranya Algemeen Secretarie en de Daarbij Gedeponeerde Archieven 1945-1949. Selain itu saya juga menggunakan surat kabar yang meliput secara lengkap peristiwa revolusi sosial yang terjadi di
Simalungun pada zamannya. Serta ada beberapa saksi hidup peristiwa tersebut yang sempat diwawancarai sebagai informan. Hal ini dipaparkan dengan tujuan agar peserta mendapat contoh pengambilan data dalam menulis buku.

\section{Pemaparan tips untuk ide kreatif menulis}

Pada kegiatan ini memberikan penjelasan kepada peserta cara menemukan ide kreatif dalam menulis. Ide kreatif mampu dihasilkan oleh setiap manusia dengan cara mereka masing-masing. Tulisan yang kreatif dapat membuat para pembaca tertarik untuk menuntaskan bacaan buku mereka. Banyak orang yang mengalami kesulitan dalam menemukan ide dalam menulis buku. Mereka mencari sesuatu yang jauh tidak mudah dijangkau padahal mereka dapat menemukan ide dari kehidupan sekitar mereka. Berikut ini disampaikan beberapa tips untuk mendapat ide kreatif dalam menulis yaitu a) kejadian yang dialami; b) bidang yang dikuasai; c) pengalaman orang lain; d) sesuatu yang tengah viral/booming; e) hobi; dan f) tontonan film dan buku.

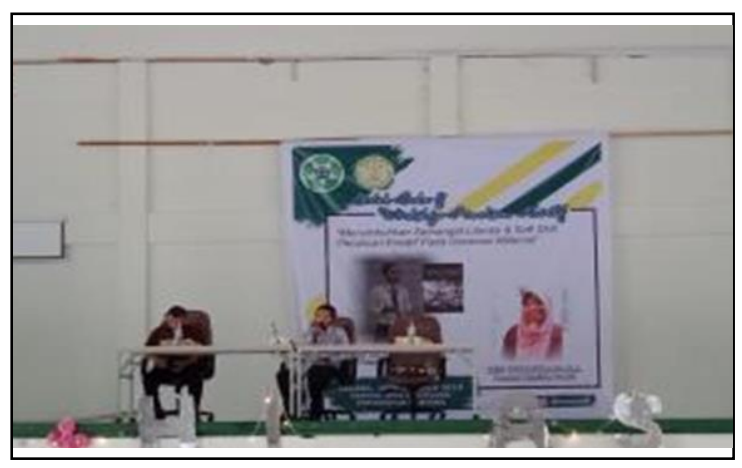

Gambar 2. Presentasi Materi Oleh Tim 
DOI: https://doi.org/10.31004/abdidas.v1i3.32

\section{Pemaparan tentang cara pengiriman dan penerbitan tulisan}

Kegiatan ini dilakukan dengan tujuan agar memberikan pengetahuan kepada peserta cara menerbitkan buku. Banyak dari peserta yang terkendala sebagai penulis pemula dalam menerbitkan buku. Untuk setiap penerbit berbeda-beda langkah untuk mempublikasikan tulisan. Tim pengabdian memberikan pengalaman dalam penerbitan buku pada penerbit Deepublish sebagai penerbit buku Laskar Revolusioner Sumatera Timur.

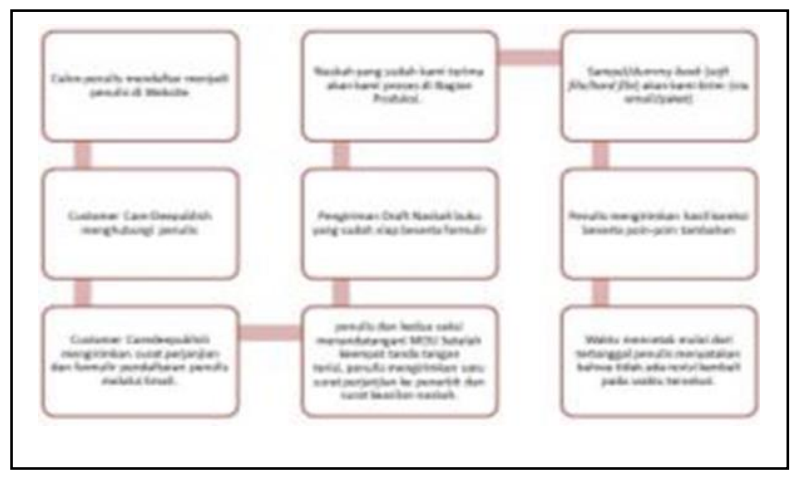

Gambar 3. Langkah menerbitkan buku pada

Penerbit Deepublish (Deepublish, 2019)

Pada setiap penerbit berbeda langkahlangkah penerbitan bukunya. Saat ini setiap penerbit mempunyai website sendiri yang memudahkan para penulis untuk mengaksesnya. Pada website tersebut berikan langkha-langkah dalam penerbitan buku bahkan sampai pendistribusian dan penjualan buku nantinya.

\section{Pemaparan teknik penulisan kreatif}

Pada kegiatan ini dilakukan dengan tujuan agar peserta dapat mengetahui langkah dalam menulis kreatif. Sehingga nantinya dapat mempraktikkan secara mandiri kegiatan menulisnya. Pemaparan teknik menulis ini dengan teknik quantum writer yakni dengan empat tahap, yakni (1) pusatkan pikiran, (2) atur, (3) karang, dan (4) hebat (DePorter, 2009, pp. 17-61). Sistem ini bisa digunakan untuk berbagai jenis tulisan. Permasalahan penulis pemula adalah tidak mengetahui cara memulainya. Ada dua hal yang dipikirkan oleh penulis pemula yaitu pertama suara kreatif terus mencoba ide-ide baru. Kedua adalah kritik batin terhadap kesalahan struktur, kesalahan tata bahasa, dan ide yang diulang. Tapi kedua hal ini harus menjadi pertimbangan untuk terus menulis.

Langkah pertama dari sistem quantum writer adalah pusatkan pikiran. Pusatkan pikiranmu adalah dengan mendengarkan suara kreatif, meningkatkan konsentrasi dan menulis gagasan pada kertas. Ada dua cara untuk menuangkan ide. Pertama, dengan menggunakan strategi gugus. Caranya yaitu kita dapat mengambil kertas kosong tanpa garis. Gunakan kertas secara horizontal. Mulailah dari bagian tengah kertas dengan menggambar lingkaran. Pada lingkaran tersebut tulislah topik utama tulisan. Kemudian buatlah cabang-cabang yang mewakili subtopik dari ide tulisan yang ditulis pada lingkaran. Di setiap subtopik buat lagi cabang terusan dan tuliskan ide lain dari subtopik pada lingkaran. Lakukan penambahan cabang sampai penulis tidak memiliki ide lagi.

Pada pemusatan pikiran dilakukan dengan cara menulis cepat. Setelah gugus pikiran telah terbuat, penulis perlu melakukan kritikan. 
Penulis menghilangkan ide-ide yang tidak ingin dipakai dan menambahkan pada ide utama. Beri angka semua ide dengan urutan yang penulis inginkan ada di draf.

Langkah kedua dari sistem quantum writer adalah atur. Setelah menuliskan ide-ide terbaik pada curah gagasan yang telah dibuat adalah dengan menatanya agar pembaca bisa membaca dengan jelas dan kuat. Strategi yang dapat digunakan untuk mengatur curah gagasan adalah dengan peta pikiran. Peta pikiran dibuat dengan menuliskan ide utama pada tengah kertas. Kemudian menambahkan cabang yang tebal dari ide utama kemudian semakin menipis jika jauh dari ide utama. Semakin tebal cabang artinya semakin penting cabang tersebut. Cabang dibuat dengan memberikan warnawarna berbeda. Selanjutnya strategi kerangka membantu membangun paragraf kuat secara rapi membangun ide dan lebih menjelaskan tulisan. Pada awal paragraf dijelaskan ide pokok paragraf. Baris selanjutnya dituliskan penjelasan yang dapat mendukung dalam menjelaskan ide pokok paragraf.

Langkah ketiga dari sistem quantum writer adalah karang. Tahap karang ini kita menggunakan strategi target dan membuat kerangka tulisan menjadi lebih bernilai (Porter: 2009:39). Kita menentukan jangka waktu mengerjakan tulisan, target pasar pembaca tulisan, alasan menulis, tujuan tulisan, motivasi, dampak pada pembaca yang ingin dirasakan pembaca.

Kemudian menulis draf tulisan serta mengoreksinya. Gunakanlah peta pikiran atau kerangka paragraf yang telah dibuat sebelumnya. Aturlah paragraf yang ingin dibuat terlebih dahulu dengan memberikan urutan atau kode tertentu. Kemudian poleslah draf tulisan yang telah dibuat dengan mengembangkan ide dan memperluas sasaran dan makna dihasil akhir tulisan.

Langkah ketiga dari sistem quantum writer adalah hebat. Pada sistem ini terdapat dua strategi yang dapat dilakukan yaitu hebat kreatif dan hebat kritik. Dua strategi untuk menambahkan daya tarik dan memeriksa akurasi tulisan. Hal digunakan untuk mengoptimalkan tulisan dan mendapatkan hasil yang diinginkan. Pada strategi hebat kreatif perhatikan tulisan yang menunjukkan, ungkapan, kiasan, dan klise.

Strategi kedua yaitu hebat kritik dengan cara pemeriksaan tulisan secara detail. Kegiatan ini bisa dilakukan oleh orang lain untuk lebih meningkatkan ketelitian. Akhirnya, periksa kembali detail seperti ejaan, kata sambung, dan tata bahasa. Ada tiga teknik hebat kritik ini memeriksa akurasi keseluruhan draf tulisan yaitu (1) baca nyaring, (2) renungkan, dan (3) tukar dengan teman.

\section{Pendampingan dan praktik tentang menulis} kreatif.

Kegiatan praktik yang dilakukan oleh peserta dilakukan dalam kelas-kelas kecil di daerah Meurandeh. Pada kegiatan ini peserta mempraktikkan cara menulis kreatif berdasarkan quantum writer. Praktik ini dimulai dari kegiatan memusatkan pikiran. Peserta diminta membuat mencurahkan gagasan pada satu lembar kertas kosong yang 
DOI: https://doi.org/10.31004/abdidas.v1i3.32

akan diisi dengan ide-ide yang ada di dalam otak mereka. Ide-ide tersebut dituliskan dengan beberapa kata kunci. Setelah itu peserta diminta untuk menentukan ide yang akan dipakai dalam tulisan dengan memberikan kode tertentu. Sedangkan ide yang tidak cocok dengan tema tulisan dapat dibuang.

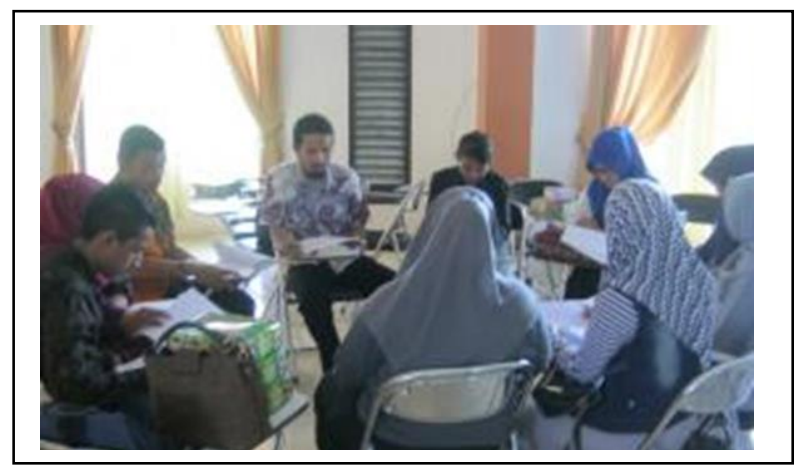

Gambar 4. Pendampingan Menulis Kreatif Secara Berkelompok Pada Peserta

Langkah kedua dengan sistem atur. Peserta diminta untuk membuat peta pikiran dari curah gagasan yang telah mereka buat tadi. Peta pikiran dibuat pada kertas kosong dengan membuat ide utama di tengah kertas. Kemudian menambahkan cabang untuk ide tambahan tulisan. Setiap cabang dari ide tersebut diberikan warna dan semakin keujung cabang akan semakin menipis. Selanjunya peserta membuat kerangka tulisan untuk membuat paragraf kuat secara rapi. Peserta diminta untuk menentukan target tulisan. Seperti lama bekerja dalam menulis, siapa pembaca, alasan, tujuan, semangat, perasaan dalam pembuatan tulisan. Selanjutnya peserta diminta untuk membuat draf tulisan dari peta pikiran dan kerangka paragraf. Langkah keempat adalah hebat. Pada langkah ini peserta diminta untuk memoles dengan menambahkan daya tarik dan memeriksa akurasi dalam tulisan.

\section{SIMPULAN}

Kesimpulan dari kegiatan pelatihan ini adalah pemahaman peserta dalam menulis kreatif dan publikasinya sangat masih terbatas. Namun, peserta sangat antusias untuk memahami untuk mengetahui pentingnya menulis kreatif sesuai dengan tahap menulis quãntum writer. Peserta termotivasi untuk berpartisipasi aktif untuk menulis sendiri sesuai dengan ide dan kemampuan yang mereka miliki.

\section{DAFTAR PUSTAKA}

BPS. (2018). Statistik Daerah Kota Langsa 2018. Badan Pusat Statistik Kota Langsa.https://langsakota.bps.go.id/publicati on/download.html?nrbvfeve=OTI2MzMxOG M5Njg5Y2YzZTMzNmQxNmNl\&xzmn=aH R0cHM6Ly9sYW5nc2Frb3RhLmJwcy5nby5 pZC9wdWJsaWNhdGlvbi8yMDE4LzEyLzA 1LzkyNjMzMThjOTY4OWNmM2UzMzZk MTZjZS9zdGF0aXNOaWstZGFlcmFoLWtv dGEtbGFuZ3NhLTIwMTguaHRtbA\%3D\%3 D\&twoadfnoarfeauf $=\mathrm{MjAyMC0}$ wNi0yMyA xNzo0MjoyMQ\%3D\%3D

Deepublish. (2019). Cara Menerbitkan Buku. Deepublish.https://penerbitdeepublish.com/ca ra-menerbitkan-buku/

DePorter, B. (2009). Quantum Writer. Kaifa.

IKAPI. (2015). Buku Indonesia dalam Angka.Www.Ikapi.Org.https://www.ikapi.org /riset/

OECD. (2019). PISA 2018 Results.CombinedExecutive Summaries (Vols. 1-3). OECD. https://doi.org/10.1017/CBO9781107415324. 004 
108 Pelatihan Soft Skill Penulisan Kreatif Pada Generasi Milenial di Kota Langsa - Hanif Harahap, Dini Ramadhani

DOI: https://doi.org/10.31004/abdidas.v1i3.32

Tarigan, H. G. (2008). Membaca sebagai Suatu

Keterampilan Berbahasa. Angkasa. 